\title{
Notes
}

\section{"INTIMATE DETAILS": A TROUBLING NEW FOURTH AMENDMENT STANDARD FOR GOVERNMENT SURVEILLANCE TECHNIQUES}

\author{
MERRICK D. BERNSTEIN
}

\section{INTRODUCTION}

In an age in which the government can see through walls with "night vision," electronagnetic detection devices, ${ }^{2}$ and other advanced technology, ${ }^{3}$ privacy rights are once again under attack. Police use thermal imaging devices to detect the "heat signatures" of our bodies and other sources in our homes; yet, a number of federal circuit courts have held that such intrusion is not a Fourth Amendment "search," and thus does not require a warrant:" the intrusion takes place without case-by-case judicial review, and

1. See, e.g., Janice Fioravante, Night Sight, INVESTOR's BusINESS DAILY, Feb. 26, 1995, at A6 ("Night vision] technology is gaining acceptance in public safety applications such as law enforcement, drug interdiction, search and rescue, as well as industrial markets.").

2. See Anna-Maria Goossens, New Security Solution in Works, DAILY HAMPSHIRE GAZETTE, July 27, 1996, at 9 (describing recent surveillance technology capable of "reading" electromagnetic radiation).

3. See Max Glaskin, Detector Frisks From a Distance, SUNDAY TIMES (London), Feb. 26, 1995 (" $[T]$ he new [thermal imaging] device does not need to bathe the subject in radiation so anyone, anywhere can be 'frisked' unknowingly, either by a fixed machine or one held by hand .... The technology even has the ability to penetrate many common building materials and allow reinote observation of people within a room."); Earl Lane, High-Tech Weapons For Cops, NEWSDAY, Aug. 2, 1994, at B25 (describing other high-technology equipment being employed by local police forces, including "smart guns" that will not fire for unauthorized users; "sniffers" that detect the presence of bullets in a building; automated booking stations to process arrestees; computerized criminal history systems; and acoustic sensors that rapidly detect, recognize and pinpoint the location of gunfire).

4. See, e.g., United States v. Myers, 46 F.3d 668 (7th Cir.), cert. denied, 116 S. Ct. 213 (1995). However, when government conduct constitutes a "search" within the Fourth Amendment, "[t] he Supreme Court has long expressed a strong preference for searches made pursuant to a search warrant, and on occasion has even asserted 'that the police must, whenever practicable, obtain advance judicial approval of searches and seizures.'" YALE KAMISAR ET AL., MODERN CRMMINAL PROCEDURE 224 (8th ed. 1994) (citations omitted). 
individuals are left without constitutional protection from indiscriminate and arbitrary police conduct. ${ }^{5}$ As a sign of things to coine, the Baltimore Police Department is currently scheduling implementation of Millivision, a passive device that perceives electromagnetic energy emitted by the body. ${ }^{6}$ The teclinology allows its user to "see" througl clothing and walls to detect whether an individual is carrying weapons, drugs, or otler objects. ${ }^{7}$ This Note argues that, in response to law enforcement's use of these new teclinologies, courts must reexamine Fourth Amendment doctrine with regard to government surveillance.

\section{The Fourth Amendment provides:}

The right of the people to be secure in their persons, houses, papers, and effects, against unreasonable searches and seizures, shall not be violated, and no Warrants shall issue, but upon probable cause, supported by Oath or affirmation, and particularly describing the place to be searched, and the persons or things to be seized. ${ }^{8}$

Early Fourth Amendment jurisprudence was constructed around property rights, protecting individuals from physical trespass ${ }^{9}$ by government agents in certain "constitutionally protected area[s]." The standard provided adequate protection against "liands-on," pliysical searclies. ${ }^{11}$ However, over time the same evaluation has

\section{.5. See, e.g., United States v. Chadwick, 433 U.S. 1, 9 (1977).}

The judicial warrant has a significant role to play in that it provides the detached scrutiny of a neutral magistrate, which is a more reliable safeguard against improper searches than the hurried judgment of a law enforcement officer "engaged in the often competitive enterprise of ferreting out crime." Once a lawful search has begnn, it is also far more likely that it will not exceed proper bounds when it is done pursuant to a judicial authorization "particularly describing the place to be searched and the persons or things to be seized." Further, a warrant assures the individual whose property is searched or seized of the lawful authority of the executing officer, his need to search, and the limits of his power to search.

Id. (citations omitted).

6. See Jennifer Tanaka \& N'gai Croal, $A$ New Way to Spot Weapons, NEwsweEk, July 31,1995 , at 8 .

7. See id. at 8.

8. U.S. CONST. amend. IV.

9. See, eg., Olmstead v. United States, 277 U.S. 438, 463, 466 (1928) (holding that a police wiretap was not proscribed by the Fourth Aniendment because the interception was accomplished without physical entry upon defendant's premises).

10. See, e.g., Silverman v. United States, 365 U.S. 505, 510, 512 (1961) (holding that eavesdropping accomplished by means of an electronic device that penetrated premises occupied by petitioner was a violation of Fourth Amendnient).

11. See id. at 509-10 ("[E]avesdropping accoinplished by neans of . . a physical 
proven inadequate to address concerns about developing surveillance techniques ${ }^{12}$ that are physically unintrusive. ${ }^{13}$

The Court initially responded to the advent of more powerful surveillance methods by shifting away from its property rights reasoning. In Katz $v$. United States, ${ }^{14}$ the Court announced that the Fourth Amendment protects people, not places. ${ }^{15}$ From Katz forward, the Court decided, an individual's reasonable expectation of privacy would govern whether or not a particular government activity constitutes a "search" within the ambit of the Fourth Amendment. ${ }^{16}$ Despite this attempt to respond to advancing technology, ${ }^{17}$ subsequent decisions have revealed an unwillingness on the part of the Court to apply this constitutional scrutiny to newer, more powerful governmental surveillance techniques. ${ }^{18}$

Moreover, recent Supreme Court cases demonstrate a refinement. The Court is beginning to conduct a new inquiry-an imqui-

intrusion" without a warrant amounts to an invasion of Fourth Amendinent rights).

12. As early as 1928, Justice Brandeis warned against the future implications of adopting a "physical trespass" interpretation of the Fourth Amendment as technology advanced:

In the application of a Constitution, our contemplation cannot be only of what has been but of what may be. The progress of science in furnishing the Govemment with means of espionage is not likely to stop with wire-tapping. Ways may some day be developed by which the Government, without removing papers from secret drawers, can reproduce them in court, and by which it will be enabled to expose to a jury the most intimate occurrences of the home. Advances in the psychic and related sciences unay bring means of exploring unexpressed beliefs, thoughts and emotions. "That places the liberty of every man in the hands of every petty officer" was said by James Otis of inuch lesser intrusions than these. To Lord Camden a far slighter intrnsion seenned "subversive of all the comforts of society." Can it be that the Constitution affords no protection against such invasions of individual security?

Olmstead, 277 U.S. at 474 (Brandeis, J., dissenting).

13. See Dow Chem. Co. v. United States, 476 U.S. 227, 247 (1986) (Powell, J., concurring in part and dissenting in part) (stating that the reasonable expectation of privacy standard was designed to ensure that the Fourth Amendment continues to protect privacy in an era when official surveillance can be accomplished without any physical intrusion).

14. 389 U.S. 347 (1967).

15. See id. at 351.

16. See id. at 361 . The actual test has two requirements: first, that a person has exhibited an actual (subjective) expectation of privacy and, second, that the expectation be one that society is prepared to recognize as "reasonable." Id. (Harlan, J., concurring).

17. See id. at 362 (Harlan, J., concurring).

18. See, e.g., Dow, 476 U.S. at 239 (holding that the taking of aerial photographs with a precise and expensive camera of the industrial complex of a chemical coinpany was not a "search" governed by the Fourth Amendment); Smith v. Maryland, 442 U.S. $735,745-46$ (1979) (holding that the nse of a pen register by a teleplone company does not constitute a search within the meaning of the Fourth Amendment); see also infra notes $41-62$ and accompanying text. 
ry ex post into the content of the information revealed by surveillance-instead of the manner in which the information has been obtained. ${ }^{19}$ Although the Court still putatively adheres to the Katz standard, much of its recent reasoning seems to be based on the Court's behef that certain government activities are not searches because the "intimate details" of individuals' hives are not revealed in the process. ${ }^{20}$ Without further defining these "intimate details," the federal circuit courts have seized this reasoning ${ }^{21}$ and have proposed that whether government surveillance has revealed "intimate details" should be the "crucial inquiry" in determining whether Fourth Amendment protection is available. ${ }^{22}$

This Note argues that the U.S. Supreme Court is likely to adopt this "intimate details" standard, drainatically altering the balance between the government's interest in effective surveillance and citizens' privacy rights. New, physically-unintrusive yet extremely revealing government surveillance techmques will not be considered "searches" and, as a result, mdividuals will be deprived of Fourth Amendment protection froin such government conduct.

19. See, e.g., Dow, 476 U.S. 227; supra note 13 and accompanying text.

20. See, e.g., Dow, 476 U.S. at 238 ("[The photographs at issue] are not so revealing of intimate details as to raise constitutional concerns."); California v. Ciraolo, 476 U.S. 207, 215 n.3 (1986) ("[A]erial observation of curtilage may become invasive, either due to physical intrusiveness or through modern technology which discloses to the senses those intimate associations, objects or activities otherwise imperceptible to police or fellow citizens."); Florida v. Riley, 488 U.S. 445, 452 (1989) (When a helicopter flew at 400 feet over respondent's curtilage, there was no evidence in the record that "intimate details connected with the use of [his] home or curtilage were observed."). Curtilage includes "those out-buildings which are directly and intimately connected with the habitation and in proximity thereto and the land or grounds surrounding the dwelling which are necessary and convenient and habitually used for family purposes and carrying on domestic employment." BLACK's LAW DICTIONARY 384 (6th ed. 1990).

21. See, e.g., United States v. Ishmael, 48 F.3d 850, 855 (5th Cir.) (holding that a warrantless use of a thermal imager did not violate the Fourth Ainendment (citing Dow, 476 U.S. at 238)), cert. denied, 116 S. Ct. 75 (1995); United States v. Ford, 34 F.3d 992, 996 (11th Cir. 1994) (citing Oliver v. United States, 466 U.S. 170, 181 (1984)) (holding that defendant did not have a reasonable subjective expectation of privacy in heat which was vented from his mobile home and which was detected by infrared thermal images).

22. See Ishmael, 48 F.3d at 855; Ford, 34 F.3d at 996 (citing Riley, 488 U.S. at 452); see also United States v. Myers, 46 F.3d 668, 669-70 (7th Cir.) (holding that thermal imagery is not a "search" within the meaning of the Fourth Amendment), cert. denied, 116 S. Ct. 684 (1995); United States v. Kyllo, 37 F.3d 526, 530-31 (9th Cir. 1994) (holding that determination of whether use of thermal inaging device to scan defendant's residence was a search required remand for findings on technical capacity of device); United States v. Pinson, 24 F.3d 1056, 1058-59 (8th Cir. 1994) (holding that defendant's subjective expectation of privacy in heat emanating from his house was not one that society would find objectively reasonable). 
Furthermore, because of the surreptitious nature of many new surveillance techniques, individuals will be unaware when the techniques are in use, and thus will be unable to detect or prevent government abuse. The checks on government surveillance that previously lad limited government intrusion into our private lives will be severely reduced, and much that individuals have long considered private will be open to arbitrary and capricious police inspection.

Part I of this Note discusses the development of Fourth Amendinent jurisprudence regarding "searches," and recognizes the implicit adoption of an "intimate details" test in response to emerging technological advances. Part II discusses one such technological advance, thermal imaging, and reviews the federal circuit courts' explicit use of the "intimate details" standard in determining whetlier use of that technology constitutes a "search" under the Fourth Amendment. Part III attempts to develop a working definition of "intimate details" and discusses the constitutionality of warrantless use of Millivision, a new, highly-powerful surveillance technology, in light of this definition. Part III concludes that warrantless Millivision scans and other high technology surveillance techniques are unlikely to be considered "searches" under the Fourth Amendment. Part IV refocuses on the "intimate details" standard itself, and argues that it is flawed: the standard is illdefined and overly-generous to police surveillance techniques. Because the "intimate details" standard appears to be the Court's current response to emerging pliysically-unintrusive surveillance techniques, and because it is not amenable to primcipled limitation, Part IV argues that new restraints need to be applied to balance the interests of law enforcement and the individual. To achieve that goal, this Note offers two proposals: 1) limiting the capacity of the technology; and 2) placing the burden of proof on the government to demonstrate that the "search" revealed no "intimate details."

\section{THE SUPREME COURT'S FOURTH AMENDMENT JURISPRUDENCE}

The Fourth Amendment provides direct protection from "unreasonable government mvasions of legitimate privacy interests."23

23. See United States v. Chadwick, 433 U.S. 1, 11 (1977). 
The drafters of the Bill of Rights adopted the Fourth Amendment against the backdrop of the arbitrary and abusive system of Writs of Assistance used by tax collectors and other governmental officials in colonial times. ${ }^{24}$ This practice is undoubtedly the historical reason that warrantless searches are presumed unreasonable $e^{25}$ unless they fall into one of the exceptions to the warrant requirement. ${ }^{26} \mathrm{~A}$ prerequisite to invoking the protection of the amendment, however, is that the government activity in question constitute a search. ${ }^{27}$ The Supreme Court has struggled to define the term "search" for Fourth Amendment purposes. Early decisions held that a government activity only constituted a search if the government physically trespassed on certain "constitutionally protected areas. .28

24. See Chadwick, 433 U.S. at 7-8 (stating that the Fourth Amendment "grew in large measure out of the colonists' experience with Writs of Assistance"); Boyd v. United States, 116 U.S. 616, 623-29 (1886) (stating that the Framers' colonial experience with Writs of Assistance informed their conception of what was meant by unreasonable searches and seizures).

25. See, e.g., California v. Carney, 471 U.S. 386, 390 (1985) ("This fundamental right is preserved by a requirement that searches be conducted pursuant to a warrant issucd by an independent judicial officer."); Boyd, 116 U.S. at 627 ("Such is the power, and, therefore, one would expect the law to warrant [general searches] should be clear in proportion as the power is exorbitant.").

26. See California v. Acevedo, 500 U.S. 565, 582 (1991) (Scalia, J., concurring). [T] he warrant requirement [has] become so riddled with exceptions that it [is] basically unrecognizable. In 1985, one commentator cataloged nearly 20 such exceptions, including "searches incident to arrest .... automobile searches... border searches ... administrative searches of regulated businesses . . . exigent circumstances .... search[es] incident to nonarrest when there is probable cause to arrest ... boat boarding for document checks ... welfare searches ... inventory searches ... airport searches ... [and] school search[es]."

Id. (quoting Craig M. Bradley, Two Models of the Fourth Amendment, 83 MICH. L. REV. 1468, 1473-74 (1984)).

27. See Maryland v. Macan, 472 U.S. 463, 469 (1985) (holding that absent a search or seizure, Fourth Amendment safeguards do not apply); see also, e.g., Anthony G. Amsterdam, Perspectives on the Fourth Amendment, 58 MINN. L. REV. 349, 356 (1974) (noting that "[1]aw enforcement practices are not required by the Fourth Amendment to be reasonable unless they are either 'searches' or 'seizures" ").

28. Lopez v. United States, 373 U.S. 427, 438-39 (1963) (upholding the admissibility of an electronic recording of petitioner's conversation, and noting that there was no unlawful physical invasion of a constitutionally protected area); see also Silverman v. United States, 365 U.S. 505, 510, 512 (1961) (holding the actions of police officers in attaching a "spike mike" to a heating duct of house used by defendants violated the Fourth Amendment because it was accomphshed through unauthorized physical penetration into the premises occupied by the petitioners); Olmstead v. United States, 277 U.S. 438, 466 (1928) (holding that, because a wiretap did not involve entry into the defendant's house, its use did not violate the Fourth Amendment). 
The belief that the Fourth Amendment protects individuals from more than just physical searches has existed for more than a century. ${ }^{29}$ That belief is currently embodied in Katz $v$. United States. ${ }^{30}$ In Katz, Government agents had attached an electromic listening device to a public telephone booth from which the petitioner had placed a call. ${ }^{31}$ The contents of this call were part of the state's case, $m$ which the petitioner was convicted of transmitting wagering information by telephone in violation of a federal statute. ${ }^{32}$ The Court decided that the conversation overheard by the government agents should have been suppressed at trial as the fruits of an illegal search. ${ }^{33}$ In Katz, the Court overturned the premise that property interests control the right of government to search and seize, ${ }^{34}$ holding instead that the Fourth Amendment "protects people, not places."

The primary inquiry under Justice Harlan's concurring analysis in Katz, which has become the controlling Fourth Amendment test, ${ }^{36}$ is whether an individual's expectation of privacy is one that society is willing to recognize as reasonable. ${ }^{37}$ If the Court finds the expectation to be reasonable, the government activity is deemed a "search," and unless the government had a warrant or the "search" fell into one of the exceptions to the warrant requireinent, ${ }^{38}$ the evidence obtamed in the search is inadmissible at trial. ${ }^{39}$ However, if the Court finds the expectation is not objectively reasonable, the Fourth Amendment is held not to apply, and any evidence garnered from the search is admissible. ${ }^{40}$ Thus, the cru-

29. See Boyd, 116 U.S. at 630 (1886) ("[I]t is not the breaking of [Petitioner's] doors, and the rummaging of his drawers, that constitutes the essence of the offense; but it is the invasion of his indefeasible right of personal security, personal liberty and private property").

30. 389 U.S. 347 (1967).

31. See id. at 348.

32. See id.

33. See id. at 359 .

34. See id. at 353 (holding that "the reach of that Amendment cannot turn upon the presence or absence of a physical intrusion into any given enclosure").

35. Id. at 351 .

36. See, e.g., Dow Chemical Co. v. United States, 476 U.S. 227, 230, 236 (1986).

37. See Katz, 389 U.S. at 360 (Harlan, J., concurring).

38. For an account of such exceptions, see supra note 26.

39. See Katz, 389 U.S. at 359 (reversing defendant's conviction, based on trial court's admission of illegally seized conversation).

40. See California v. Greenwood, 486 U.S. 35, 45 (1988) (reversing trial court's suppression of evidence because the seizure did not infringe a reasonable expectation of 
cial determination is the definition of reasonableness of the defendant's expectation of privacy.

Since Katz, several decisions have shed some hight on how the Court determines when an individual has a "reasonable expectation of privacy," or, im other words, when specific government conduct constitutes a "search" deserving of Fourth Amendment scrutiny. ${ }^{41}$ In Smith v. Maryland, ${ }^{42}$ the Court held that the use of a pen register ${ }^{43}$ by the phone company upon the request of police did not constitute a "search" within the meaning of the Fourth Amendment. ${ }^{44}$ The Court analyzed the pen register under the Katz standard and held that the individual in question had no legitimate expectation of privacy in the numbers he dialed. ${ }^{45} \mathrm{By}$ the Court's reasoning, the fact that individuals voluntarily convey phone numbers to the telephone company dictates the conclusion that those individuals forfeit any expectation of privacy they otherwise might have had in the subject matter. ${ }^{46}$ Also important in the Court's reasoning was the inability of the pen register to reflect the contents of communications. ${ }^{47}$ The Court coinpared the phone numbers revealed by the police in this case with the conversation seized in $K a t z$ and concluded the two were deserving of different treatment. ${ }^{48}$

Justice Stewart, in his dissent, found the situation in Smith similar to Katz and further asserted that the petitioner's expectation of privacy was one that society would deem reasonable. ${ }^{49} \mathrm{He}$

privacy).

41. See, e.g., California v. Ciraolo, 476 U.S. 207 (1986); Dow Chem. Co. v. United States, 476 U.S. 227 (1986).

42. 442 U.S. 735 (1979).

43. "A pen register is a mechanical device that records the numbers dialed on a telephone by monitoring the electrical impulses caused when the dial on the telephone is released. It does not overhear oral communications and does not indicate whether calls are actually completed." Id. at 736 n.1 (quoting United States v. New York Tel. Co., 434 U.S. 159, 161 n.1 (1977)).

44. See id. at $745-46$.

45. See id. at 743 ("[E]ven if petitioner did harbor sone subjective expectation that the phone numbers he dialed would renain private, this expectation is not 'one that society is prepared to recognize as 'reasonable."' (quoting Katz v. United States, 389 U.S. 347, 361 (1967))).

46. See id. at $742-43$.

47. See id. at 741.

48. See id. The Court noted that the pen register does not disclose the content of any communication between the caller and the recipient of the call, their identities, or whether the call was even completed. See id.

49. See id. at 747 (Stewart, J., dissenting). 
declined to follow the majority's opinion that only the content of communications was protected:

I doubt there are any [telephone subscribers] who would be lappy to have broadcast to the world a list of the local or long distance numbers they have called. This is not because such a list might in some sense be incriminating, but because it easily could reveal the identities of the persons and the places called, and thus reveal the most intimate details of a person's life..$^{50}$

This was the first time a member of the Court used the phrase "intimate details" in the context of the Fourth Amendment. Justice Stewart concluded by noting that "the broad and unsuspected governmental incursions into conversational privacy which electronic surveillance entails necessitate the application of Fourth Amendment safeguards." 51

The first appearance of the "intimate details" rationale in a majority opinion occurred in Dow Chemical Co. v. United States, ${ }^{52}$ where the Court held that aerial photography of a chemical company's industrial complex was not a "search" for Fourth Amendment purposes. ${ }^{53}$ Here again, the Court analyzed the governmental conduct and determined that the petitioner did not have a legitimate expectation of privacy in the open areas of the industrial complex. ${ }^{54}$ Writing for the majority, Chief Justice Burger distinguished the covered buildings and offices in the complex, in which Dow had a legitimate expectation of privacy, from the remainder of the complex and concluded, "[t]he intimate activities associated with family privacy and the home and its curtilage sin-ply do not reacli the outdoor areas or spaces between structures and buildings of a manufacturing plant."

Although Dow had gone to great lengths to maintain "elaborate security" at the complex, it did not conceal all of its inanufacturing equipment from aerial view. ${ }^{56}$ The Court stressed that the

50. Id. at 748 (Stewart, J., dissenting).

51. Id. at 746 (Stewart, J., dissenting) (quoting United States v. United States Dist. Court, 407 U.S. 297, 313 (1972)). Justice Marshall, in a separate dissent, noted the chilling effect that such an invasion could have on political affiliations, a free press, and other "hallmark[s]" of a true democracy. See id. at 751 (Marshall, J., dissenting).

52. 476 U.S. 227 (1986).

53. See id. at 239.

54. See id.

55. See id. at 236 .

56. See id. at 229. 
EPA aircraft was lawfully within navigable airspace when it photographed the complex, and therefore the government was not physically trespassing on Dow's property. ${ }^{57}$ Also pivotal to the case's outcome was the Court's view that the EPA was not using a unique sensory device, but rather a camera, albeit an extremely precise and expensive one, ${ }^{58}$ and that the photographs taken "[were] not so revealing of intimate details as to raise constitutional concerns." 59

Thus, the majority agam defined the constitutionality of the government surveillance by the subject inatter revealed. The Court held that if the government's actions could record conversations, see inside buildings, or reveal other intimate details, the "search" might coine within the ambit of Fourth Amendinent protection. ${ }^{60}$ In his dissent, Justice Powell, joined by Justices Brennan, Marshall, and Blackmun, vigorously argued that although the majority did not explicitly reject the apphication of the Katz standard, the majority's decision could not be reconciled with that precedent. ${ }^{61}$ Justice Powell further asserted that Dow did liave an expectation of privacy througliout its complex that society was prepared to recognize as reasonable. ${ }^{62}$

In California v. Ciraolo, ${ }^{63}$ decided the same day as Dow, the Court held that warrantless aerial observation of a fenced-in back-

57. The majority cited Oliver v. United States, 466 U.S. 170, 179 (1984), for the proposition that the "public and police lawfully may survey land from the air." Id at 238. However, as Justice Powell's dissenting opinion pointed out, "[t]he Court's holding that the warrantless photograply does not constitute an unreasonable search within the meaning of the Fourth Amendment is based on the absence of any physical trespass-a theory disapproved in a line of cases beginning with the decision in Katz v. United States." Id. at 252 (Powell, J. dissenting).

58. See id. at 238. The majority distinguished the standard floor-mounted, precision aerial mapping cainera used by the Environmental Protection Agency in the instant case from highly sophisticated surveillance equipment not generally available to the public. See id. However, as Justice Powell recognized, "[t]he Court holds that Dow had no reasonable expectation of privacy from surveillance accomplished by means of a $\$ 22,000$ mapping camera, but that it does have a reasonable expectation of privacy from satellite surveillance and photography. This type of distinction is heretofore wholly unknown in Fourth Amendment jurisprudence." Id. at 250 n.12 (Powell, J., dissenting).

59. Id. at 238. The federal circuit courts frequently cite this language when upholding physically unintrusive government surveillance. See, e.g., United States v. Ford, 34 F.3d 992, 996 (11th Cir. 1994); United States v. Kyllo, 37 F.3d 526, 531 (9th Cir. 1994).

60. See Dow, 476 U.S. at 238-39.

61. See id. at 244-47 (Powell, J., dissenting).

62. See id. at $248-49$.

63. 476 U.S. 207 (1986). 
yard within the curtilage of a home was not a "search" under the Fourth Amendment. ${ }^{64}$ For the Court, the test of legitimacy under Katz did not depend on whether an individual chooses to conceal an assertedly private activity, but rather whether the government's intrusion infringes upon the values protected by the Fourth Amendment. ${ }^{65}$ The Court acknowledged that "aerial observation of curtilage may become mvasive, either due to physical intrusiveness or through modern technology which discloses to the senses those intimate associations, objects or activities otherwise imperceptible to police or fellow citizens." however, that no such details were revealed in the instant case, and therefore that the petitioner could not have a reasonable expectation of privacy. ${ }^{67}$

Writing for the same four justices dissenting in Dow, Justice Powell described the "indiscriminate nature" of the surveillance; the photographs revealed not only respondent's curtilage, but his house and the houses and yards of his neighbors. ${ }^{68}$ Justice Powell agaim admonished the Court that modern technology poses an mcreasing threat to the individual's personal freedoms and liberties. ${ }^{69}$ Justice Powell argued that the majority's opinion strayed from the standard established in Katz: "It is not easy to believe that our society is prepared to force individuals to bear the risk of
64. See id. at 215 .
65. See id. at 211-12.
66. Id. at 215 n.8 (quoting Brief for Petitioner at 14-15) (emphasis added).
67. See id. at 212-14.
68. See id. at 225 (Powell, J., dissenting).

The Court's decision has serious implications for outdoor family activities conducted in the curtilage of a home. The feature of such activities that makes them desirable to citizens living in a free society, namely, the fact that they occur in the open air and sunlight, is relied on by the Court as a justification for permitting police to conduct warrantless surveillance at will. Aerial surveillance is nearly as intrusive on family privacy as physical trespass into the curtilage. It would appear that, after today, families can expect to be free of official surveillance only when they retreat behind the walls of their homes.

Id. at 225 n.10.

69. See id. at 226. Powell stated:

Rapidly advancing technology now permits police to conduct surveillance in the home itself, an area where privacy interests are most cherished in our society, without any physical trespass. While the rule in Katz was designed to prevent silent and unseen invasions of Fourth Amendment privacy rights in a variety of settings, we have consistently afforded heightened protection to a person's right to be left alone in the privacy of his house. The Court fails to enforce that right or to give any weight to the longstanding presumption that warrantless intrusions into the home are unreasonable.

Id. (footnote omitted). 
this type of warrantless police intrusion into their residential areas. $" 970$

The "intimate details" test next appeared in the Court's decision in California v. Greenwood. ${ }^{71}$ There the Court held that individuals do not have a reasonable expectation of privacy in garbage placed in opaque bags outside their louses for collection by the sanitation department. ${ }^{72}$ The majority, using the Katz standard, concluded that although the petitioner was adlering to a local ordinance in disposing of his trasl at the curb, he voluntarily conveyed it to third parties such as "animals, children, scavengers, [or] snoops." "73 The dissent argued that society should protect as reasonable the petitioner's expectation of privacy because a "single bag of traslı" reveals the "intimate details" of an individual's life. ${ }^{74}$

In the latest Supreme Court case to address the constitutionality of warrantless government surveillance, the Court again used the "intimate details" rationale, this time emphasizing that this language was central to its lolding. In Florida v. Riley, ${ }^{75}$ Justice White wrote a plurality opinion that upheld the constitutionality of a law enforcement officer's observation, with his naked eye, from a helicopter circling at an altitude of 400 feet, of the interior of a partially covered greenhouse in a residential backyard. ${ }^{76}$ The Court held that this surveillance did not constitute a "search" for whicl a warrant was required. ${ }^{77}$ Even though the respondent had surrounded his yard with wire fencing and had posted "Do Not Enter" signs, and even thougl the greenhouse was "obscured from view from surrounding property by trees, shrubs, and the mobile home," "no intimate details connected with the use of the hoine or curtilage were observed,"79 and therefore, the Court lield, the

70. Id. at 225 (footnote omitted).

71. 486 U.S. 35 (1988).

72. See id. at $40-41$.

73. Id. at 40 (citations omitted).

74. Id. at 50 (Brennan, J., dissenting) ("Like rifling through desk drawers or intercepting phone calls, rummaging through trash can divulge the target's financial and professional status, political affiliations and inclinations, private thoughts, personal relationships, and roinantic interests.").

75. 488 U.S. 445 (1989).

76. See id. at $450-51$.

77. See id. at 450 .

78. Id. at 448.

79. Id. 
surveillance was not a "search" that violated his reasonable expectation of privacy. ${ }^{80}$ What makes this decision so remarkable is that the Court had previously considered the curtilage of one's home as deserving the same paramount protection as the inside of the hoine itself. ${ }^{81}$ Under the Court's holding in Riley, however, it is apparent that the home is no longer afforded such blanket protection. Instead, what is "seen" will be determinative of the constitutionality of the warrantless surveillance.

In a lengthy dissent in Riley, Justice Brennan asked "[w]hat, one wonders, is meant by 'intimate details'?" out that the Fourth Amendinent does not require that the activity observed be "intimate" to deserve protection. ${ }^{83}$ These points highlight the failure of the Court to sufficiently describe what "intimate details" are and why they matter to Fourth Amendinent jurisprudence. The plurality in Riley only refers to them vaguely. ${ }^{84}$ Smith, Dow, Ciraolo and Greenwood explam only what they are not..$^{85}$ Is one to suppose that an "intimate detail" is apparent only in the way "obscenity" was pinned down by Justice Stewart? ${ }^{86}$ Despite the lack of definition, in Riley an embrace of the "intimate details" standard by at least a plurality of the Court has becoune clear.

\section{Thermal ImAgING AND THE "INTIMATE DetaILs" STANDARD}

While the Supreme Court appears to be using the "intimate details" language to determine the constitutionahity of physically unintrusive government surveillance techniques, it has failed to define this standard clearly. The circuit courts have begun to provide this definition in cases that go beyond the kind of direct visual surveillance found in Riley, especially those that consider the

80. See id. at 452 .

81. See Dow Chem. Co. v. United States, 476 U.S. 227, 235-36 (1986).

82. Riley, 488 U.S. at 463 (Brennan, J., dissenting).

83. See id. at 464 (Brennan, J., dissenting) ("If the Constitution does not protect Riley's marijuana garden against such surveillance, it is hard to see how it will prohibit the government from aerial spying on the activities of a law-abiding citizen on her fully enclosed outdoor patio.").

84. See id. at 452 (stating only that "no intimate details . . . were observed").

85. See supra notes $42-74$ and accompanying text.

86. See Jacobellis v. Ohio, 378 U.S. 184, 197 (1964) (Stewart, J., concurring) (defining obscenity: "I know it when I see it"). 
government's warrantless use of thermal imaging technology. ${ }^{87}$ These lower courts have determined that the "crucial question" in determining whether a government surveillance is constitutional is whether "intimate details" are revealed. ${ }^{88}$ Instead of focusing broadly on whether a person's expectation of privacy was objectively reasonable, they have focused narrowly on the content of what was observed. ${ }^{89}$ They have held that unless a particular government technology reveals a couple making love or some other similarly "intimate" activity, it will not be considered a "search" deserving of Fourth Amendinent protection. ${ }^{90}$ This reasoning by the circuit courts could have devastating effects on individuals' privacy interests. Until the Supreine Court addresses this issue, the "intimate details" test is law in these circuits. Thus, law enforcement officers in these jurisdictions are permitted nearly unlimited use of physically unintrusive surveillance techniques, and may proceed, unchecked, to investigate homes and persons in highly invasive ways.

\section{A. Thermal Imaging Technology}

"Thermal imagery" is the use of infrared detection equipment to produce a visual image of an object from the heat it radiates. ${ }^{91}$ The image is created when the thermal imaging device converts the thermal energy radiating froin the object into a color on a predetermined color scale. ${ }^{92} \mathrm{~A}$ screen then shows the object in slightly less detail than a television picture, ${ }^{93}$ and shows which objects are radiating more or less heat than a baseline set by the operator. ${ }^{94}$ To calibrate the device for a neighborhood sweep, the

87. See infra notes $104-42$ and accompanying text.

88. See, eg., United States v. Ishmael, 48 F.3d 850, 855 (5th Cir.), cert. denied, 116 S. Ct. 75 (1995).

89. See, e.g., id.

90. See United States v. Kyllo, 37 F.3d 526, 530 (9th Cir. 1994) (holding that reference to the factual basis of the case, including whether "the device can detect sexual activity in the bedroom," is required to determine if a thermal scan constitutes a "search" under the Fourth Amendnient).

91. See United States v. Field, 855 F. Supp. 1518, 1522 (W.D. Wis. 1994). Thermal imagers, relying on differences in radiant heat from objects, are distinct from the electroinagnetic imaging used by Millivision and similar devices. See infra notes 174-88 and accompanying text.

92. See Field, 855 F. Supp. at 1522

93. See id.

94. See id. 
operator scans neighboring homes where the owners are not suspected of criminal activity. ${ }^{95}$ The device is passive, that is, it does not project beams or otherwise physically penetrate the objects targeted. ${ }^{96}$ Neither the heat sources nor the infrared waves of radiating heat are visible to the naked eye. ${ }^{97}$

Thermal imagery has been used extensively im various military actions, including most famously the Persian Gulf War, for military coinbat apphications such as weapons targeting. ${ }^{98}$ Presently, this technology is gaining acceptance in various public safety apphications. ${ }^{99}$ While there are a range of uses to which thermal imagery can be put, the Drug Enforcement Agency (DEA) and local and state pohice primarily use the device for profiling indoor marijuana growing operations. ${ }^{100}$ Whether using thermal imaging systems built into airborne surveillance vehicles or hand-held units, agents "look for hot spots that would indicate heat sources inside a building." "101 Such lieat sources enanate from high intensity discharge hights which generate heat of 150 degrees or more $\mathrm{e}^{102}$ and which are necessary for indoor inarijuana-growing operations. The results of these thermal scans aid law enforcement in obtaining searcli warrants for the premises. ${ }^{103}$

\section{B. Constitutionality of Warrantless Thermal Imaging "Searches" Under the Fourth Amendment}

All five Circuit Courts that have addressed the use of thermal imaging devices without a search warrant liave determined it to be constitutional under tlie Fourth Amendinent. ${ }^{104}$ In each of these

95. See Washington v. Young, 867 P.2d 593, 600 (Wash. 1994).

96. See Field, 855 F. Supp. at 1522.

97. See id.; Young, 867 P.2d at 595 .

98. See Fioravante, supra note 1, at A6; see also Lynne M. Pochurek, From the Battlefront to the Homefront: Infrared Surveillance and the War On Drugs Place Privacy Under Siege, 7 ST. Thomas L. REv. 137, 149 (1995). "The FLID [Forward Looking Infrared Device] was designed to advance the United States' position in military conbat. This thermal iniagery equipment enables its user to sense surface temperatures to 'see' through darkness, haze or smoke." Id. (footnote omitted).

99. See Fioravante, supra note 1 , at A6.

100. See Pochurek, supra note 98 , at 150 .

101. Field, 855 F. Supp. at 1522.

102. See United States v. Pimson, 24 F.3d 1056, 1057 (8th Cir. 1994).

103. See, e.g., id. at 1058.

104. See United States v. Ishmael, 48 F.3d 850, 853 (5th Cir.), cert. denied 116 S. Ct. 75 (1995); United States v. Myers, 46 F.3d 668, 669-70 (7th Cir.), cert. denied, 116 S. Ct. 
cases, government agents used thermal imagers to detect the presence of hot spots that allegedly indicated that grow lights were being operated to aid the cultivation of marijuana plants. ${ }^{105}$ And, in each case, the agents used the results of the thermal scans as support to obtain a search warrant for the defendants' premises. ${ }^{106}$ The various defendants moved to suppress the thermal imaging evidence on the grounds that the warrantless use of the thermal imaging device was unconstitutional; thus, they argued, the search warrant was mvalid, and all its fruits should be excluded at trial. ${ }^{107}$

The Eighth Circuit was the first to review the warrantless use of thermal imagers. In United States $v$. Pinson, ${ }^{108}$ the court lield that the defendant's Fourth Amendment rights were not violated by the government's use of the device. ${ }^{109}$ The court reviewed the case under the Katz analysis and concluded that, even if the de-

213 (1995); United States v. Ford, 34 F.3d 992, 997 (11th Cir. 1994); Pinson, 24 F.3d at 1058-59; United States v. Kyllo, 37 F.3d 526 (9th Cir. 1994). But see United States v. Cusumano, 67 F.3d 1497, 1500-01 (10th Cir. 1995), vacated en banc, 83 F.3d 1247 (10th Cir. 1996) (raising the possibility that thermal scans without a warrant violate the Fourth Amendnient and arguing that other circuit courts have "misframed" the Fourth Amendnient inquiry). For a more detailed analysis of the circuit courts' thermal imaging cases, see Pochurek, supra note 98, at 151-59; Lisa Tuenge Hale, Comment, United States v. Ford: The Eleventh Circuit Permits Unrestricted Police Use of Thermal Surveillance on Private Property Without A Warrant, 29 GA. L. REV. 819 (1995); Susan Moore, Note, Does Heat Emanate Beyond the Threshold?: Home Infrared Emissions, Remote Sensing, and the Fourth Amendment Threshold, 70 CHI.-KENT L. REV. 803 (1994); Matthew L. Zabel, Comment, A High-Tech Assault on the "Castle": Warrantless Thermal Surveillance of Private Residences and the Fourth Amendment, 90 Nw. U. L. REv. 267, 282-287 (1995).

105. See Ishmael, 48 F.3d at 851-52; Myers, 46 F.3d at 669; Ford, 34 F.3d at 993; Pinson, 24 F.3d at 1057-58; Kyllo, 37 F.3d at 528.

106. See Ishmael, 48 F.3d at 851-52; Myers, 46 F.3d at 669; Ford, 34 F.3d at 993; Pinson, 24 F.3d at 1057-58; Kyllo, 37 F.3d at 528.

107. See Cusumano, 67 F.3d at 1499; Ishmael, 48 F.3d at 851-52; Myers, 46 F.3d at 669; Ford, 34 F.3d at 993; Pinson, 24 F.3d at 1057. In Mapp v. Ohio, 367 U.S. 643 (1961), the Suprene Court held that the exclusionary rule applies to the states. See id. at 655. The exclusionary rule provides that evidence obtained by violating a defendant's constitutional rights may not be introduced by the prosection for the purposes of providing direct proof of the defendant's guilt. See id. at 646-50. The Supreme Court has held, however, that the rule is not required by the Constitution. See United States v. Leon, 468 U.S. 897, 906-07 (1984) ("Whether the exclusionary rule is appropriately imposed in a particular case ... must be resolved by weighing the costs and benefits of preventing the use [of the defective evidence]."). Instead, it is a judicially-created method of deterring violations of the Fourth Amendment. See KAMISAR, supra note 4, at 208-34.

108. 24 F.3d 1056 (8th Cir. 1994).

109. See id. at 1059 . 
fendant had a subjective expectation of privacy, it was not one that society was prepared to recognize as "reasonable."110 The court likened the thermal scan to the warrantless use of police dogs trained to sniff for and identify the presence of drugs, ${ }^{111}$ upheld by the Supreme Court in United States v. Place. ${ }^{112}$ The Eighth Circuit stated:

The detection of the heat waste was not an intrusion into the home; no intimate details of the home were observed, and there was no intrusion upon the privacy of the individuals within. None of the interests which form the basis for the need for protection of a residence, namely the intimacy, personal autonomy and privacy associated with a home, are threatened by thermal imagery. ${ }^{113}$

While not specifically referring to $D o w,{ }^{114}$ it appears that the Eighth Circuit was influenced by that decision and similar postKatz Fourth Amendment jurisprudence. ${ }^{115}$

Similarly, the defendant in United States v. Ford ${ }^{116}$ contested the admissibility of evidence obtained through a search of his hoine. ${ }^{117}$ In this case, the warrant was partly based on the results of a thermal scan conducted by police that revealed the defendant's home was emitting an "inordinate amount of heat."118 The Eleventh Circuit concluded that the defendant did not have a subjective expectation of privacy because he had taken intentional steps to vent the heat that was detected by the thermal

110. See id. at 1058-59.

111. See id. at 1058.

112. 462 U.S. 696,707 (1983) (holding that the use of a police-trained dog in a public place does not constitute a search for purposes of the Fourth Amendinent); see also Cusumano, 67 F.3d at 1508-09:

The dog sniff, like the thermal imager, extracts information about the interior

of an object solely froin an analysis of external physical phenomena ....

[However, as] the imager lacks the precision of the dog sniff, we decline to extend Place to allow the warrantless use of thermal imagers upon a hoine. Id.

113. Pinson, 24 F.3d at 1059.

114. 476 U.S. 227 (1986).

115. Like Dow and Katz, Pinson einphasized that the challenged search did not intrude upon any reasonable expectation of privacy. Pinson, 24 F.3d at 1058-59; see also Dow, 476 U.S. at 238-39; Katz v. United States, 389 U.S. 347, 360-61 (1967) (Harlan, J., concurring).

116. 34 F.3d 992 (11th Cir. 1994).

117. See id. at 993.

118. Id. 
imager. ${ }^{119}$ Furthermore, the court said that even if Ford had a subjective expectation of privacy, it was not one which society was prepared to recognize as reasonable. ${ }^{120}$ The test of reasonableness, explained the court, was determined by referring to the fundamental values of the Fourth Amendment. "One such value that has emerged as a significant factor in the Court's Fourth Amendment analysis is the mtimacy of detail and activity that a surveillance technique reveals in a particular case." ${ }^{\text {2121 }}$ The court cited Dow for the primciple that even if sophisticated surveillance equipment is used, unless the government activity reveals intimate details, no warrant will be required by the Fourth Amendment. ${ }^{122}$ The court then concluded that as far as the record revealed, "no intimate details connected with the use of the home or curtilage were observed," and that there was therefore no Fourth Amendment violation. ${ }^{123}$

In United States $v$. Kyllo, ${ }^{124}$ the Nimth Circuit elaborated on the "intimate details" standard developed by the Eleventh and Eighth Circuits. In Kyllo, the defendant appealed the denial of a motion to suppress all evidence found in a search of his residence. ${ }^{125}$ The warrant was again partly predicated on the results of a thermal scan of his residence. ${ }^{126}$ The court remanded the case to the district court for a factual determination of the technological capacity of the thermal imaging device. ${ }^{127}$ The court said it needed a factual basis on which to determine whether the defendant had a reasonable expectation of privacy. ${ }^{128}$ The district court was directed to determine whether "on the one extreme, this device can detect sexual activity in the bedroom, ... or at the other extreme, whether it can only detect hot spots where heat is escapimg from a structure." 129 The Ninth Circuit, like the Eighth

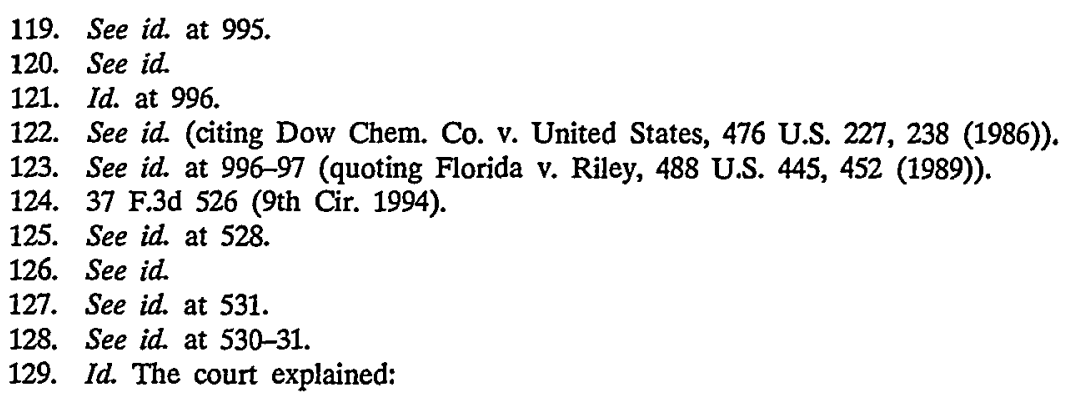

[W] must decide whether Kyllo exhibited an actual expectation of privacy and whether that expectation is one that society is prepared to acknowledge as reasonable. But this inquiry cannot be conducted in the abstract. We must have 
Circuit, cited Dow for the now-familiar proposition that particular warrantless government surveillance will only be unconstitutional if it reveals "intimate details." 130 But the Ninth Circuit added a twist: a requirement to investigate the capacity of the thermal imaging device to reveal intimate details. Presumably, if the device could reveal human forms and their activities, the court was prepared to hold the "search" unconstitutional. ${ }^{131}$

On remand, the district court found that the use of the thermal imaging device "was not an intrusion" into defendant's home. ${ }^{132}$ The court found that "[n]o intimate details of the home were observed, and there was no intrusion upon the privacy of the individuals within the home." 133 The district court made the factual finding that the thermal imaging device conld not penetrate the walls or windows to reveal conversations or human activities. ${ }^{134}$ Therefore, at least in the context of the scope of the thermal imaging used in Kyllo, the use of the technology is not a "search" within the ineaning of the Fourth Amendinent in the Ninth Circuit. ${ }^{135}$

The next case to hold that a warrantless thermal scan of defendant's hoine was not a "search" within the meaning of the Fourth Amendment came from the Seventh Circuit, which in United States v. Myers ${ }^{136}$ relied on the "persuasive" reasoning of the Eighth and Eleventh Circuits in its decision. ${ }^{137}$ Citing Pinson, the Myers court held that even if the defendant had a subjective expectation of privacy, society was not prepared to recognize that

some factual basis for gauging the intrusiveness of the thermal imaging device, which depends on the quality and the degree of detail of information that it can glean.

Id. (citations omitted).

130. See id. at 531 n.3 (citing Dow, 476 U.S. at 238).

131. See id. at 530-31.

132. United States v. Kyllo, No. CR. 92-51-FR, 1996 WL 125594, at *2 (D. Or. Mar. 15, 1996).

133. Id. at $* 2$.

134. See id.

135. See id. The factual findings of the district court involved the particular thermal imaging device used by the Oregon National Guard in this particular case (the AGEMA Thermovision 210). See id. Presumably, a different district court could find that a different thermal imaging device can actually reveal "intimate details." However, it appears that warrantless thermal imaging scans, in general, will not be held unconstitutional under similar facts.

136. 46 F.3d 668 (7th Cir.), cert. denied, 116 S. Ct. 213 (1995).

137. See id. at 669 . 
expectation as reasonable because "[n]one of the interests which form the basis for the need for protection of a residence, namely the intimacy, personal autonomy and privacy associated with a hoine, are threatened by thermal imagery."138

Finally, the Fifth Circuit in United States v. Ishmael ${ }^{139}$ concluded that "[ $[$ ] $]$ he crucial inquiry, as in any search and seizure analysis, is whether the technology reveals "intimate details" 140 and upheld a warrantless thermal scan of defendant's property. ${ }^{141}$ The court specifically held that the thermal imager is acceptable because it does not reveal intimate details within the structure being scanned and therefore does not violate any Fourth Amendment principles. ${ }^{142}$

The only circuit to date to raise the possibility that a warrantless therinal scan could constitute a search for Fourth Amendment purposes has been the Tenth Circuit, in United States v. Cusumano. ${ }^{143}$ In Cusumano, the initial panel decision coinpared the "bug" at issue in Katz to the therinal scan used by police to detect marijuana growing operations: ${ }^{144}$

[T] he bug at issue in Katz was fixed to the outside of a public plione booth. Reduced to its operational fundainentals, that bug did not monitor the interior of the plione booth at all; rather, it ineasured the molecular vibrations of the glass that encoinpassed that interior. Alternatively, it might fairly be said that the bug passively recorded the propagation of waste vibrational energy into the public sphere. Drawing upon the logic embraced by our fellow circuits, one could reason that the translation of the vibrational record into an account of that which transpired within the plione booth was simply a useful interpretation of abandoned energy - an analysis which would, we note, approve the search condernned by Katz. ${ }^{145}$

138. Id. at 670 (quoting United States v. Pinson, 24 F.3d 1056, 1059 (8th Cir. 1994)).

139. 48 F.3d 850 (5th Cir.), cert. denied, 116 S. Ct. 75 (1995).

140. Id. at 855 .

141. Id. (citing Dow, 476 U.S. at 238).

142. See id. at 856. ("[T] he device assesses only heat differentials in objects and therefore poses no threat to the privacy concerns that the Fourth Amendment is intended to protect.").

143. 67 F.3d. 1497 (10th Cir. 1995), vacated on reh'g en banc, 83 F.3d 1247 (10th Cir. 1996).

144. See id. at 1501.

145. Id. 
The panel stated that the Katz Court did not look at the devices employed by the government nor the physical properties of the recorded information, but rather to the object of the government's efforts. ${ }^{146}$ Further, the panel suggested, the appropriate question is not how capable a device is of revealing intimate details; the question to be asked is whether the device was used to momitor an activity in the home, a place deserving of the most exacting Fourth Amendment protection. ${ }^{147}$ However, on rehearing en banc, ${ }^{148}$ the majority ${ }^{149}$ decided not to decide whether the use of a thermal imager was a search under the Fourth Amendment because, "absent any consideration of the information obtained from the warrantless use of the thermal imager, the affidavit established probable cause to support issuance of the search warrant."150 Thus, the issue of the constitutionality of the warrantless use of thermal imaging remains technically unaddressed in the Tenth Circuit.

All of the federal circuit courts that have definitively addressed the warrantless use of thermal imaging devices appear to agree that this technology is not subject to Fourth Amendment scrutiny. These courts have relied heavily on the dicta in Dow and other post-Katz cases and therefore have considered the "crucial question" to be whether the device reveals "intimate details." In this attempt to flesl out the phrase "reasonable expectation of privacy," a new definition of "search" for Fourth Amendment purposes appears to be emerging. ${ }^{152}$ Government surveillance is only a "search," it seems, when that surveillance reveals "intimate details." If certain government conduct, sucl as thermal imaging, reveals these intimate details, it will generally have to be conducted pursuant to a warrant. If, on the other hand, the court determines that such details were not revealed, the activity does not constitute a "search," and the Fourth Amendment standard does

146. See id. at $\mathbf{1 5 0 2 .}$

147. See id. at 1502-03 (citing United States v. Karo, 468 U.S. 705, 714 (1984)); see also Payton v. New York, 445 U.S. 573, 590 (1980) ("[T]he Fourth Amendment has drawn a firm line at the entrance to the house. Absent exigent circumstances, that threshold may not reasonably be crossed without a warrant.").

148. United States v. Cusumano, 83 F.3d 1247 (10th Cir. 1996).

149. There were three dissenters in the decision. See id.

150. Id. at 1248 .

151. See supra text accompanying note 140.

152. See supra notes $104-42$ and accompanying text. 
not apply. Should the Supreme Court follow the circuit courts and explicitly adopt this definition of "search," as it appears prepared to $\mathrm{do}^{153}$ an increased government intrusion into private lives will becoine an acceptable practice.

\section{Millivision AND the "INTIMATE DetaIls" Test}

Millivision is one of many high technologies that can "search" an individual without physical intrusion. ${ }^{154}$ While this technology inay provide many advantages to law enforceinent, it also raises serious constitutional issues. The Supreme Court is at a crossroads in its Fourth Amendment jurisprudence, and its decisions on the constitutionality of technologies like Millivision will largely determine the scope of permissible government investigation into individuals' private lives. Instead of focusing on objective expectations, the Court now examines the subject matter revealed by the surveillance. If what is "seen" is deeined by the Court to be "intimate," the surveillance will be considered a search and will be subject to the warrant requirement; if what is "seen" is not "intimate," the surveillance can be conducted without judicial scrutiny. There are many dangers inherent in this inethod of reviewing government conduct, especially in light of the surreptitious nature of the technology. Foremost among these is that without a working definition of "intimate details," law enforcement officers will not know the acceptable parameters of their activities; neither will individuals know what to expect. Individuals also will be unaware of the existence of the surveillance and ignorant of government abuses. Defining what "intimate details" are, therefore, will be the first step in determining the scope of permissible surveillance.

153. Although there is no precedential value in decisions by the Court to decline petitions for certiorari, it is noteworthy that the Supreme Court has declined to review three of the four circuit court decisions discussed supra. See United States v. Myers, 116 S. Ct. 213 (1995) (denying certiorari review); United States v. Ishmael, 116 S. Ct. 75 (1995) (same); United States v. Pinson 115 S. Ct. 664 (1994) (saine). No petition for certiorari was filed in United States v. Ford, 34 F.3d 992 (11th Cir. 1994); the issue in United States v. Kyllo, 37 F.3d 526 (8th Cir. 1994) was renanded to the lower court, with no possibility yet for Suprenue Court review.

154. See infra notes $174-88$ and accompanying text. 


\section{A. The "Intimate Details" Standard Defined}

The threshold question raised by the "intimate details" test is the one posed by Justice Brennan in Riley: "What, one wonders, is meant by "intimate details"?"155 In order to define "intimate details," one must refer back to the text of the Fourth Amendment and its interpretation by the Court. In his dissenting opinion in California v. Ciraolo, ${ }^{156}$ Justice Powell recalled that the Fourth Amendment "reflects a choice that our society should be one in which citizens 'dwell in reasonable security and freedom from surveillance." 157 Justice Powell stated:

While no single consideration has been regarded as dispositive, "the Court has given weight to such factors as the intention of the Framers of the Fourth Amendment, ... the uses to which the individual has put a location, ... and our societal understanding that certain areas deserve the inost scrupulous protection from government invasion." 158

However, if the "intimate details" test is formally adopted by the Court, it is difficult to see how the privacy interests cited by Justice Powell can be protected. The "intimate details" standard removes from the analysis any consideration of how and where the government is conducting its surveillance. Instead, the analysis focuses on the particular subject inatter being "searched."159 It appears froin the jurisprudence of the Court that the fact that the search takes place in and around a home, previously a place deserving of the utinost privacy, is no longer the important factor in the analysis. ${ }^{160}$ Rather, the government could conduct surveillance without warrant in any location, so long as it only found items that would not be considered "intimate details."161 Addi-

155. Florida v. Riley, 488 U.S. 445, 463 (1989) (Brennan, J., dissenting).

156. 476 U.S. 207 (1986).

157. Id. at 217 (Powell, J., dissenting) (quoting Johnson v. United States, 333 U.S. 10, 14 (1948)).

158. Id. at 220 (quoting Oliver v. United States, 466 U.S. 170, 182 (1984)).

159. See supra text accompanying notes $46-47$.

160. See Riley, 488 U.S. at 458-63 (Brennan, J., dissenting) (stating that the consequence of the plurality's analysis is that Fourth Amendment riglts are infringed only if police surveillance "interferes with the use of the backyard as a garden spot," id. at 463, presuming that the police performing the surveillance were within their rights in being where they were).

161. See, e.g., United States v. Ford, 34 F.3d 992 (11th Cir. 1994) (holding that the use of a thermal imager did not constitute a "search" because no intimate details were 
tionally, the test has been applied even if the surveillance technology at issue had the capability of revealing these "intimate details," unless the individual could prove that the particular warrantless government surveillance actually revealed such details, the surveillance would be constitutionally permissible. ${ }^{162}$ This result contravenes the basic premise of the Fourth Amendment and the Court's holdimg in Katz. ${ }^{163}$ Nevertheless, this is unquestionably the direction the Court has been taking in its decisions since Katz. ${ }^{164}$

In Florida v. Riley, ${ }^{165}$ a plurality of the Court said that police could "search" the curtilage of an individual's home from the air, ${ }^{166}$ as long as the "search" did not reveal any "intimate details." ${ }^{" 167}$ While the Court had previously considered the curtilage of one's property deserving of the same protection as the home itself, ${ }^{168}$ the Court declined to extend this protection to the plaintiff because no "intimate details" were revealed. ${ }^{169}$ Again Justice Brennan, im his dissent, posed a relevant question: "If the police laad observed Riley embracing his wife in the backyard greenhouse, would we then say that his reasonable expectation of privacy had been infringed?"'170

A hypothetical similar to that discussed by Justice Brennan would reveal another absurd result. What would the Court conclude if the helicopter in Riley had looked through a skylight in the bedroom ceiling to find marijuana plants growing at the bedside? Because both the curtilage and the home itself have been extended similar privacy expectations, presumably the Court, con-

revealed).

162. See, e.g., Riley, 488 U.S. at 455 (holding that police conduct was not a search when no intimate details were actually observed).

163. See, e.g., Dow Chem. Co. v. United States, 476 U.S. 227, 243-44 (1986) (Powell, $\mathrm{J}$., concurring in part and dissenting in part) (contending that the majority's opinion to permit aerial photographs of an industrial plant does not square with the decision in Katz).

164. See supra notes $41-86$ and accompanying text.

165. 488 U.S. 445 (1989).

166. While the search in Riley actually revealed the curtilage of the property, the Supreme Court has considered the curtilage deserving of the same protection as the house. See id. at 452 (O'Cormor, J. concurring).

167. See id. (emphasizing the importance of curtilage in Fourth Amendment doctrine as an area intimately linked to the liome).

168. See supra note 81 and accompanying text.

169. See Riley, 488 U.S. at 455.

170. Id. at 463 (Brennan, J., dissenting). 
sistent with its prior holdings, would allow the government to "peek" through the skylight as long as the helicopter was in a place where it could legally be. ${ }^{171}$ According to this reasoning, because the bedroom was left exposed via the skylight to anybody who wanted to hover over the house, one has lost any expectation of privacy. However, if while the government was looking through the skylight to see the marijuana plants, they observed the residents making love, or writing in a diary, or reading certain books, or other "intimate details" of one's life, the search would, under a literal reading of Riley, be unconstitutional.

This hypothetical is only one of countless imaginable hypotheticals that leave one feeling somewhat insecure about the ability to protect one's privacy from arbitrary and indiscriminate government surveillance. It is important to note that, although the defendant in Riley was "suspected" of growing inarijuana, the Court's holding allows the police to search any yard, regardless of whether or not they suspect an individual of criminal activity. ${ }^{172}$ As Justice Breman stated in his dissent:

The principle enunciated in this case determines what limits the Fourth Amendment imposes on aerial surveillance of any person, for any reason. If the Constitution does not protect Riley's marijuana garden against such surveillance, it is hard to see how it will prohibit the government from aerial spying on the activities of a law-abiding citizen on her fully enclosed outdoor patio. ${ }^{173}$

171. See id. at 450 ("The Fourth Amendment simply does not require the police traveling in the public airways at [a low] altitude to obtain a warrant in order to observe what is visible to the naked eye." (internal quotation marks omitted)).

172. See id. at 450-52. It is hard to sympathize with criminals caught red-lianded with contraband-the occasional suppression of illegally obtained evidence leaves a bad taste in our mouths. The Fourth Ameudment, however, exists to protect all individuals. "[T] liere is nothing new in the realization that the Constitution sometimes insulates the criminality of a few to protect the privacy of us all." Arizona v. Hicks, 480 U.S. 321,329 (1987). As Justice Brennan stated in his dissent in Riley,

It is indeed easy to forget, especially in view of current concern over drug trafficking, that the scope of the Fourth Amendment's protection does not turn on whether the activity disclosed by a search is illegal or innocuous. But we dismiss this as a "drug case" only at the peril of our own liberties. Justice Frankfurter once noted that "[i]t is a fair summary of history to say that the safeguards of liberty have frequently been forged in controversies involving not very nice people," United States v. Rabinowitz, 339 U.S. 56, 69 (1950) (dissenting opinion), and nowlere is this observation more apt than in the area of the Fourth Amendment, whose words have necessarily been given meaning largely through decisions suppressing evidence of criminal activity.

488 U.S. at $463-64$ (Brennan, J., dissenting).

173. Riley, 488 U.S. at 464 (Brennan, J., dissenting). 


\section{B. Millivision}

Millivision is a new surveillance technology that uses passive imaging technology to read the electromagnetic radiation emitted by an object. ${ }^{174}$ "All objects with temperatures above absolute zero naturally emit a broad spectrum of electromagnetic radiation, the details of which are determined by the material and surface properties of the object, as characterized by its emissivity, and by its temperature."175 Millivision and its accompanying "image-understanding software" read this electromagnetic radiation and convert the radiation into a visual image, similar to an $\mathrm{X}$-ray machine. ${ }^{176}$ Unlike $X$-rays, however, which are unable to detect drugs or the modern components of bomb and weapon manufacturing, Millivision is able to specifically identify most objects because of the different emissions of various materials. ${ }^{17}$ For example, an individual's clothing is virtually transparent to Millivision, while a person's body is an especially good emitter of electromagnetic radiation. Different sorts of metals and plastics are somewhere in between. ${ }^{178}$ Also unlike X-ray detectors, Millivision is passive and does not expose the subject to any man-made electromagnetic fields or other radiation from the imaging system. ${ }^{179}$

Millivision is intended to be used primarily by law enforcement officers, usually to conduct "remote frisks" of individuals to detect the presence of concealed weapons. ${ }^{180} \mathrm{~A}$ patrolman could operate the device from his car to examine an imdividual on the street from a substantial distance witlout having to leave the vehicle or physically "searcli" the individual-and without the

174. See Reducing Gun Violence: Testimony to the Crime and Criminal Justice Subcomm. of the House Comm on the Judiciary, 104th Cong. (1994) (statement of Dr. G. Richard Huguenin, President of Millitech Corporation), available in LEXIS, Legis Library, Cong. Test. File [hereinafter Huguenin Testimony].

175. Id.

176. See id.

177. See Goossens, supra note 2 , at 9.

178. See Huguenin Testimony, supra note 174. Metals are very poor emitters, while various plastics exhibit emission properties between flesh and metals. See id.

179. See id.

180. See id; see also Goossens, supra note 2, at 9; Erik Milstone, New Devices Let Frisk Go Undercover: Agency Pushes Effort While Critics Worry About Trampling Privacy Rights, A.B.A. J., Aug. 1996, at 32; Joyce Price, 'X-ray' Camera Could Reveal Criminal Intent; Civil Libertarians See Privacy Problems, WASH. Times, Aug. 13, 1996, at A1. 
individual's knowledge. ${ }^{181}$ Millivision is also capable of detecting contraband other than traditional inetal weapons concealed on individuals, including non-1netallic weapons, electronic devices, and explosives. ${ }^{182}$ Using "sniart" software, Millivision could be programmed to recognize certain shapes and indicate to the operator if one of those shapes has been detected by the machine. ${ }^{183}$ For example, the software could be programmed to recognize dry powders or liquids in plastic bags, vials, or other containers. ${ }^{184}$ While Millivision could not determine the chemical properties of the powder or liquid, it could alert the operator of the possibility of the presence of drugs, and the operator could conduct a further investigation. ${ }^{185}$

Millitech Corporation, with $\$ 1.4$ million in grants from the federal government, ${ }^{186}$ has developed a sniall hand-held Millivision camera for remote detection and is developing a larger, fixed-installation camera for airports and other entranceways. ${ }^{187}$ A prototype lias already been developed, and regular production is scheduled to begin this year. ${ }^{188}$

\section{Millivision and the Constitution}

The constitutionality of a warrantless Millivision scan must be analyzed under the framework of the Supreme Court's Fourth Amendment jurisprudence, as well as the recent circuit court decisions on thermal imaging technology. Because Millivision is similar to thermal imaging in that it is a passive and physically unintrusive surveillance technology, the same analysis used in the thermal imaging cases should apply. Thus, the determination of whether such a scan constitutes a search under the Fourth Amendment, and consequently is subject to a warrant requirement, is likely to be based on whether the scan reveals "intimate details."

181. See Huguenin Testimony, supra note 174.

182. See id.

183. See id.

184. See id.

185. See Goossens, supra note 2 , at 9.

186. See Price, supra note 180 , at A1. Funding for the camera came from the US Army and Air Force and from two international corporations. See Huguenin Testimony, supra note 174.

187. See Huguenin Testimony, supra note 174.

188. Price, supra note 180 , at A1. 
Although Millivision does literally see through clothing, "the resulting display does not reveal intimate anatomical details of the person." 189 Usmg the "smart" software discussed earlier, ${ }^{190}$ Millivision could be set so that a person with no suspicious objects could be cleared automatically without operator intervention and without an image being displayed. ${ }^{191}$ Only if the operator is alerted to the presence of a "suspicious" object would an image be displayed at all, and the resolution is not clear enough to see "the contours of breasts, buttocks and genitals." 192

Since a Millivision scan would not reveal a person's "intimate anatomical details,"193 a warrantless scan would only be unconstitutional if it revealed the "imtimate details" of something carried on the person. However, since the scan only displays the outline of these objects, as opposed to their content, in most cases the scan would not reveal anything the Court would consider "intimate." ${ }^{194}$ For example, if an individual was carrying a diary or political manifesto, Millivision could presuniably detect the outline of the book or papers, but could not detect the content of the writings. This seems to be the same distinction the majority made with respect to pen registers in Smith $v$. Maryland. ${ }^{195}$ While the Court lield the content of the teleplione conversation itself was private, the telephone number dialed, that is, to whom the call was placed, was not an "intimate detail" wortlyy of Fourth Amendment protection. ${ }^{196}$ Similarly, the warrantless thermal imaging countenanced by the circuit courts is capable of revealing "hot spots," but not the specific content of the structures from which those spots emit, and thus does "not reveal any imtimate details."197

189. Huguenin Testimony, supra note 174. The precise abilities of Millivision are currently under some debate. See Price, supra note 180 , at A1.

190. See supra notes $183-85$ and accompanying text.

191. See id.

192. Price, supra note 180 , at A1.

193. Huguenin Testimony, supra note 174.

194. While the Court has used the language of the "intimate details" analysis on several occasions, it has yet to define the standard. See supra notes 82-86 and accoinpanying text. What is apparent from the Court's jurisprudence is that the important factor is the content of the objects revealed. See, e.g., Smith v. Maryland, 442 U.S. 735, 741-46 (1979) (distinguishing between the pen register which was capable of revealing only the telephone numbers dialed, which was held not to amount to a "search," and the conversation itself, in Katz, which was deeined worthy of Fourth Amendment protection).

195. 442 U.S. 735,741 (1979); see supra notes $42-48$ and accompanying text.

196. See Smith, 442 U.S. at 742.

197. See supra notes $104-42$ and accompanying text (discussing the "intimate details" 
While one might be able to envisage some objects that by their outline alone reveal "intimate details," 198 this would not be the norm.

Similarly, if courts continue to adhere to the "intimate details" standard as it has developed in the cases subsequent to Katz, they will hold that a warrantless Millivision scan does not constitute a "search" under the Fourth Amendment. An electroinagnetic scan would only reveal suspicious objects which are outside of the scope of the "intimate details" standard. ${ }^{199}$ At this point, the court's inquiry would end and there would be no constitutional protection for individuals against arbitrary and indiscriminate Millivision scans.

At least one commentator has urged that a Millivision "frisk" should be subject to the same restrictions as a traditional stop-andfrisk by police. ${ }^{200}$ The standards for a stop-and-frisk arose in the Court's decision in Terry v. Ohio, ${ }^{201}$ where the Court held that before engaging in a traditional frisk, the police officer must have a "reasonable suspicion" that the person with whom he is dealing is armed and dangerous. ${ }^{202}$ The Court established that the "stopand-frisk" was a "search and seizure" within the meaning of the Fourth Amendment. ${ }^{203}$ Because the Court considered the search

test as used by the circuit courts in evaluating the constitutionality of thermal scans of private residences).

198. Such objects could include religious symbols or sexual paraphernalia, to name just two possibilities. Under the Court's analysis, if "intimate details" are revealed about an individual, then the search might be deemed unconstitutional. See Florida v. Riley, 488 U.S. 445,452 (1989). However, this finding would have no bearing on the constitutionality of the technology in general, as the analysis seems to be based on individual considerations. See id.

199. See, e.g., Riley, 488 U.S. at 450-52 (holding that marijuana was not an "intimate detail" worthy of constitutional protection); California v. Ciraolo, 476 U.S. 207, 213-15 (1986) (same).

200. See Milstone, supra note 180, at 33 (citing David A. Harris, law professor at the University of Toledo College of Law).

201. 392 U.S. 1 (1968).

202. See id. at 30 .

203. See id. at 15. The Court explained:

It is quite plain that the Fourth Amendment governs "seizures" of the person which do not eventuate in a trip to the station house and prosecution for crime-"arrests" in traditional terminology. It must be recognized that whenever a police officer accosts an individual and restrains his freedom to walk away, he has "seized" that person. And it is nothing less than sheer torture of the English language to suggest that a careful exploration of the outer surfaces of a person's clothing all over his body in an attempt to find weapons is not a "search." 
and seizure only minimally intrusive, ${ }^{204}$ it proceeded to determine whether the "search and seizure were unreasonable."205 This "inquiry" is a dual one-whether the officer's action was justified at its inception, and whether it was reasonably related in scope to the circumstances which justified the interference in the first place. ${ }^{206}$ This dual inquiry involved balancing the interests of the law enforcement officer in protecting himself against the intrusiveness of the search to the individual..$^{207}$

In the Millivision context, however, there are several crucial distinctions from the traditional Terry frisk. In Terry, the Court recognized that a traditional frisk involved a "seizure" and thus directly implicated the Fourth Amendment. ${ }^{20 s}$ A typical Millivision scan would be physically unintrusive; there would be no "seizure" of the person, and an individual's freedom would not be restrained. As such, constitutional protections would only be imphcated if there was a "search." As discussed above, because the scan would not reveal intimate details, a Millivision scan would not constitute a search under the Fourth Amendment. As such, a Millivision scan is inherently different from a "Terry stop," and the same standards do not apply. Thus, an individual would most likely be afforded no constitutional protection from warrantless, arbitrary Millivision "frisks."

\section{MONITORING THE GOVERNMENT'S USE OF SURVEILLANCE TECHNOLOGY}

If the Court formally adopts an "intimate details" standard for determining whether a particular government surveillance technique constituted a "search" protected by the Fourth Amendment, a vital component would be to ensure that this standard was being "scrupulously" honored by law enforceinent. ${ }^{209}$ Thermal imaging technology has the capability of distinguishing heat sources in very precise gradations: current technology can detect the tear ducts on a face. ${ }^{210}$ It would not be difficult "to identify (if not, strictly

Id. at 16.

204. See id. at 26.

205. Id. at 29-30.

206. Id. at 19-20.

207. See id.

208. See id. at 16-17.

209. See Arizona v. Hicks, 480 U.S. 321, 326-27 (1987) (arguing that police searches must be "scrupulously" subjected to Fourth Amendment inquiry).

210. See United States v. Field, 855 F. Supp. 1518, 1531 (W.D. Wis. 1994); supra 
speaking, to watch) two people making love in the privacy of their darkened bedroom." 211 Presumably, "watching" two people making love would be an "intimate detail" protected by the Fourth Amendment. ${ }^{212}$ We hope that the government will exercise great discretion in employing such technology, ${ }^{213}$ but "the very existence of such discretion would run afoul of the Constitution."214 The purpose of the warrant requirement is to imterpose some judicial impartiahty between law enforcement and the citizens. ${ }^{215}$ Since it would be unconstitutional to leave such technology in the hands of law enforcement absent some impartial constraints, two such restraints will now be briefly considered: 1) limiting law enforcement to technology that is not capable of revealing intimate details; and 2) placing the burden on the government at trial to prove that in its search for evidence, no "intimate details" were revealed.

\section{A. Limiting the Technology Available to Police}

In the marketplace for surveillance equipment, within each technology there are machines with different capabilities and levels of accuracy. ${ }^{216}$ For example, the available thermal imaging devic-

notes 91-103 and accompanying text (discussing the technological capabilities of thermal imaging devices).

211. United States v. Cusumano, 67 F.3d 1497, 1502, 1504 (10th Cir. 1995) vacated on reh'g en banc, 83 F.3d 1247 (10th Cir. 1996); see also State v. Young, 867 P.2d 593, 595 (1994) (noting that thermal imagers can detect "a human form through an open [curtamed] window when the person is leaning against [the] curtain" or a person leaning against a plywood door).

212. See, e.g., Florida v. Riley, 488 U.S. 445, 463 (1989) (Brennan, J., dissenting) ("If the police had observed Riley embracing his wife in the backyard greenhouse, would we say that his reasonable expectation of privacy had been infringed?"); United States v. Kyllo, 37 F.3d 526, 530-31 (9th Cir. 1994) (remanding to the district court for findings on whether the thermal imaging device can "detect sexual activity in the bedroom").

213. See Cusumano, 67 F.3d at 1504.

214. Id. at 1504; see also Katz v. United States, 389 U.S. 347, 357 (1967) (arguing that notwithstanding facts showing probable cause, police officers must first obtain a warrant, because "the Constitution requires 'that the deliberate, impartial judgment of a judicial officer ... be interposed between the citizen and the pohice'") (citations omitted); Boyd v. United States, 116 U.S. 616, 625-27 (1886) (arguing that the Fourth Amendment was passed as a result of the arbitrary and discretionary powers of revenue agents pursuant to the Writs of Assistance in colonial times).

215. See Coolidge v. New Hampshire, 403 U.S. 443,453 (1971) (noting that a "fundamental premise" of the warrant is review by a "neutral and detached" magistrate).

216. See Mindy G. Wilson, Note, The Prewarrant Use of Thermal Imagery: Has This Technological Advance in the War Against Drugs Come at the Expense of Fourth Amend- 
es vary in sensitivity and accuracy. ${ }^{217}$ Some of them are capable of only grossly distinguishing "hot spots" on the exterior of buildings; others can identify the novement of a human body through underbrush and fohage, ${ }^{218}$ and still others have a range of capabilities. $^{219}$ The Court could choose to hold that so long as the device could ouly vaguely detect hot spots and was incapable of revealing human forms or other details it considered intimate, the surveillance would not constitute a "search." This eminently plausible solution would limit the capacity of the government to enhance the technology to a point that revealed too much.

This solution would be compatible with the "canine sniff" held constitutional in United States v. Place. ${ }^{220}$ In Place, the Court held that the investigative procedure of subjecting luggage to a canine "sniff test" by a well-trained narcotics detection dog does not constitute a "search" within the meaning of the Fourth Amendment. ${ }^{221}$ The relative "unintrusiveness" of the canine sniff was important to the Court's analysis, as was the fact that the canine sniff is limited in its disclosure to the detection of illegal contraband and does not expose "non-contraband" items to public view. ${ }^{222}$ Thus, the Court could limit the government's use of passive surveillance to searches tailored to discover specific sorts of contraband. ${ }^{223}$ The Court could limit the use of thermal imaging technology, for instance, solely to thermal scans for "hot spots." Similarly, if a Millivision scan were targeted so that it revealed ouly the presence or absence of weapons, illegal narcotics, or other contraband, the technology would seem closely analogous to the "sniff" test. This solution appears to be conceptually similar not only to Justice O'Connor's majority opimion in Place, but also to

ment Protections Against Unreasonable Searches?, 83 KY. L.J. 891, $897-98$ (1995) (discussing the technological capabilities of thermal imaging devices).

217. See id. at $897-98$.

218. See Cusumano, 67 F.3d at 1504.

219. See Wilson, supra note 216 , at $897-98$.

220. 462 U.S. 696 (1983).

221. See id. at 706-07. A "sniff-test" involves a police dog smelling a closed piece of luggage for odors of certain kinds of contraband, usually narcotics. See id.

222. See id. at 707.

223. While the canine sniff is discriminating in its ability to disclose any details of the individual, in that the dog detects only contraband items, the thermal scan has the capability of revealing innocent conduct as well as the presence of marijuana. $C f$. United States v. Cusumano, 67 F.3d 1497, 1504-05, 1505 n.14 (10th Cir. 1995), vacated on reh'g en banc, 83 F.3d 1247 (10th Cir. 1996) (remanding case for a determination of whether thermal imagery could reveal innocent activity, such as baking cookies). 
Chief Justice Burger's statement in Dow that the EPA "was not employing some unique sensory device that, for example, could penetrate the walls of buildings and record conversations."224 Chief Justice Burger seems to have implicitly acknowledged that the Court must engage in some sort of analysis of the specific technologies used by the government to determine which were violative of the Fourth Amendment.

While the requirement that the Court analyze the technology used would address the concerns that surveillance might reveal too much, this judicial scrutiny raises many issues. For example, involving the courts in the constant monitoring of new technologies and nraking determinations of the level of intrusion of each brand and model of a specific technology are activities that the Court, Justice Burger's comments notwithstanding, ${ }^{225}$ would most likely be reluctant to perform. However, should the district courts begin to make factual findings, like the district court in Kyllo, ${ }^{226}$ that "no nitimate details" are revealed by a particular technology, ${ }^{227}$ the appellate courts would have an easier time finding such "searclies" constitutional. Similarly, should the Court explicitly adopt an "intimate details" standard that places limits on the specificity revealed by the technology, law enforcement might understand this as an admonition to use self-restramt in their use of higl-tech surveillance.

\section{B. Placing the Burden of Proof on the Government}

Currently, the burden at trial is on the defendant to prove that he had a "reasonable expectation of privacy" that was violated by specific police conduct. ${ }^{228}$ However, the Court could shift the burden by requiring the state to prove that its technological surveillance technique did not observe "intimate details" raising constitutional concerns. ${ }^{229}$ If this were the case, on a notion to

224. Id. at 238.

225. See id.

226. United States v. Kyllo, No. CR. 92-51-FR., 1996 WL 125594 (D. Or. March 15, 1996).

227. Id. at $* 2$.

228. See Florida v. Riley, 488 U.S. 445, 455 (1989) (O'Connor, J., concurring) (citing Jones v. United States, 362 U.S. 257, 261 (1961)); see also United States v. Evans, 27 F.3d 1221, 1228 (7th Cir. 1994).

229. Many areas of Fourth Amendment jurisprudence contain similar examples of burden-shifting. In the context of automobile searches, while the defendant bears the 
suppress evidence obtained pursuant to a search warrant, the government would have to prove, by a preponderance of the evidence, that their activity in gaining probable cause to secure the warrant did not inadvertently reveal these details. This burdenshifting might be a logical step, especially since the government activity in question will most likely be surreptitious in nature, and the individual will have little chance of knowing she is being "searclied," let alone whether the government activity revealed "intimate details." Instead, the government would be forced to record the searches and produce this recording in its entirety at trial. The court could then review the recording and determine whether "intimate details" were revealed. 230 Examples of how this solution might be applied include displaying pictures or video taken by the surveillance, as was done in Dow. ${ }^{231}$ Similarly, most other technologically advanced surveillance is recorded by computer, video, or soine other recording device. The officers who claim their warrantless surveillance activities did not reveal "intimate details" would thus have possession of the proof. It would then be for the court to examine the video, pictures, or stored computer images, and to determine if any such details are revealed. Placing the burden of proof on the government would put the onus on law enforcement to ensure continued custody of the surveillance records and it would provide a procedural safeguard to secure some degree of protection to individuals who would be subjected to warrantless government surveillance.

It would be important to ensure that this burden-shifting is not emasculated by the good faith exception to the warrant requirement, which holds that if the police reasonably believe that the warrant under which they have acted is valid, the exclusionary rule will not apply to bar the items seized from being introduced at the trial of the person whose rights were violated by the search. ${ }^{232}$ The police would be held accountable for ensuring that

burden of showing that a search occurred, the government must show that consent was given for the search. See United States v. Flores, 48 F.3d 467, 468 (10th Cir.), cert. denied, 116 S. Ct. 1260 (1995).

230. Objections about the cumbersomeness of such a review could be addressed by allowing defense attorneys to edit the recording.

231. See Dow, 476 U.S. at 238 (indicating a review of the photographs when the Court stated that "the photographs here are not so revealing of intinate details as to raise constitutional concerns").

232. See United States v. Leon, 468 U.S. 897, 925-26 (1984). 
they did not observe any "intimate details" in their activity, and as such could not believe in "good faith" that they had a valid warrant predicated on that information if they did so observe.

\section{CONCLUSION}

A review of recent Supreme Court decisions reveals the emergence of a new standard to determine whether government surveillance constitutes a "search" within the meaning of the Fourth Amendment. This "intimate details" test has appeared in reaction to the evolution of newer, less plysically intrusive government surveillance techniques. Its central inquiry is whether the surveillance activity at issue is "so revealing of intimate details as to raise constitutional concerns." ${ }^{233}$ Using this approach, the Court has refused to extend Fourth Amendment scrutiny to a number of new and powerful surveillance techniques available to the government.

Should the Court choose to formally adopt this "intimate details" standard, Fourth Amendment protections we currently enjoy will be substantially threatened. The Court has not provided a sufficient definition of "intimate details," and, as a consequence, neither law enforcement nor individuals know the parameters of the standard. As it stands, we will be protected only if a particular content of our activities is revealed. Adding to this uncertainty is the fact that the surreptitious nature of these searches makes it unlikely that we will understand the full extent and intrusiveness of the surveillance, or even that it is taking place. It is vital that conceptual and procedural safeguards be established to protect fundamental expectations of privacy, as the drafters of the Fourth Amendment originally intended. Such protections might include limiting the capacity of the technology and placing the burden of proof on the government to demonstrate that the surveillance revealed no "intimate details." At issue is "low tightly the Fourth Amendment permits people to be driven back into the recesses of their lives by the risk of surveillance."234 Under current law, powerful surveillance technologies like thermal imaging and Millivision are entirely permissible, and the recesses of our hoines

233. Dow, 476 U.S. at 238.

234. Riley, 488 U.S. at 466 (Brennan, J., dissenting) (citing Amsterdam, supra note 27, at 402 ). 
are not secure from government prying. Certainly, the Fourth Amendment means more than this. 